\title{
Protein and LDH-Isoenzyme Pattern of the Urine from Patients with Diabetes Mellitus Determined by Disc-Electrophoresis
}

\author{
L. Hemmingsen, N. Høiby and P. Kragh-Sørensen \\ Departments of Clinical Chemistry, Medicine Paediatrics, Central Hospital, Nykøbing Falster, Denmark
}

Received: October 31, 1969

\begin{abstract}
Summary. We have examined U.LDH excretion, protein excretion (a.m. Kjeldahl) and, by means of disc electrophoresis, the pattern of protein and LDH isoenzymes in urine from 73 diabetics. The diabetics are classified into JDM: 0-24 years, ADM: 25-64 years, EDM: > 65 years, Recent JDM: duration $\leq 1$ year, nephropathy: protein excretion $\geq 500 \mathrm{mg} / 24 \widehat{\mathrm{h}}$. - Conclusions: There is increased urinary protein excretion from the onset of the diabetes. Only in JDM is correlation found between duration of JDM and protein excretion, protein pattern and U-LDH excretion. In JDM, U-LDH excretion is not as sensitive as protein excretion and not as reliable in other groups of diabetics. In all diabetics LDH-I is low, and is useful for detecting the changed function of the diabetic kidney but not its severity. - Recent JDM present increased protein excretion, low proportion of albumin, selective proteinuria in the fractions of gammaglobulin and prealbumin, and low LDH-I. Diabetics with nephropathy present high protein excretion, proportionally high albumin, selective proteinuria in the fractions of albumin and transferrin, increased U-LDH excretion, and low LDH.I.
\end{abstract}

Distribution des protéines et des isoenzymes-LDH dans l'urine de malades avec diabète sucré déterminée par électrophorèse sur disque

Résumé. Nous avons examiné l'excrétion de la U-LDH et des protéines (d'après Kjeldahl) et, par électrophorèse sur disque, la distribution des protéines et des isoenzymes$\mathrm{LDH}$ dans les urines de 73 diabétiques. Les diabétiques étaient classés en JDM: $0-24$ ans, ADM: 25-64 ans, EDM: plus de 65 ans, JDM récents: durée moins d'une année, néphropathie: excrétion protéique plus de 500 $\mathrm{mg} / 24 \mathrm{~h}$. - Conclusions: L'excrétion urinaire augmentée des protéines commence déjà avec le début du diabète. Chez les JDM seulement, il existe une corrélation entre la durée du diabète et l'excrétion et la distribution des protéines et l'excrétion U-LDH. Chez eux, l'excrétion-U. LDH n'est pas aussi sensible que l'excrétion protéique et pas aussi sûre que dans les autres groupes de diabétiques. Chez tous les diabétiques, on trouve peu de LDH-I ce qui permet la détection de la fonction altérée du rein diabétique mais pas l'évaluation de sa sévérité. Des JDM récents présentent une excrétion protéique élevée, une proportion diminuée d'albumine et une protéinurie sélective des fractions de gamma-globulines et de préalbumine avec peu de LDH-I. - Des diabétiques avec une néphropathie présentent une excrétion protéique élevée avec une proportion relativement augmentée d'albumine ainsi qu'une protéinurie sélective dans les fractions d'albumine et de transferrine avec une excrétion U-LDH élevée et peu de LDH-I.

Eiweiß- und LDH-Isoenzym-Spektrum im Urin von Patienten mit Diabetes mellitus bei der Untersuchung mit Hilfe der Disc-Ellektrophorese

Zusammenfassung. Im Urin von 73 Diabetikern wurden die U-LDH-Ausscheidung, die Eiweißausscheidung (n. Kjeldahl) und mit Hilfe der Disc-Elektrophorese das Eiweiß- und LDH-Spektrum untersucht. Die Diabetiker wurden eingeteilt in: JDM: 0-24 Jahre, ADM: 25-64 Jahre, EDM: über 65 Jahre, neuentdeckter JDM: Dauer unter 1 Jahr, Nephropathie: Proteinausscheidung über $500 \mathrm{mg} / 24$ Std. - Schlußfolgerungen: Schon bei Ausbruch des Diabetes kommt es zu einer vermehrten Eiweißausscheidung im Harn. Nur bei JDM läßt sich eine Korrelation zwischen der Diabetesdauer und der Eiweißaus. scheidung, dem Proteinspektrum und der U-LDH-Ausscheidung belegen. Bei den JDM ist die U-LDH-Ausscheidung nicht so empfindlich wie der Eiweißverlust und nicht so verläßlich wie bei den anderen Teilkollektiven von Diabetikern. Alle Diabetiker wiesen ein niedriges LDH-I auf, was bei der Auffindung der eingeschränkten Funktion der diabetischen Niere, nicht aber bei der $\mathrm{Be}-$ urteilung ihres Schweregrades helfen kann. Neuontdeckte JDM zeigen eine erhöhte Eiweißausscheidung, einen niedrigen Albuminanteil und eine selektive Proteinurie in den Fraktionen des Gammaglobulins und des Präalbumins, sowie ein erniedrigtes LDH-I. - Bei den Diabetikern mit einer Nephropathie fanden sich ein ausgeprägter Eiweißverlust mit hohem Albuminanteil, eine selektive Proteinurie in den Fraktionen des Albumins und des Transferrins, eine verstärkte U-LDH-Ausscheidung und ein niedriges LDH-I.

Key-words: Disc-electrophoresis, protein pattern in urine, $\mathrm{LDH}$-isoenzymes in urine, urinary proteins in diabetes mellitus, diabetes mellitus.

\section{Introduction}

The purpose of this investigation was to examine the protein- and LDH-isoenzyme pattern in the urine from patients with Diabetes Mellitus (DM). This examination was carried out by means of disc-electrophoresis [13] modified for non-concentrated urine. It was also designed to examine the excretion of lacticacid-dehydrogenase (U-LDH) in the urine, in its own right, and in relation to the excretion of protein.

\section{Material and Method}

This investigation was a continuation of work published in an earlier paper [14]. The only change in methodology in the present investigation was the determination of U-LDH. In this investigation we have used Biochemica Test Combination UV-Test ${ }^{\circledR}$. Because of this change we examined a new normal group simultaneously with the examination of the clinical material. 
The urine samples were collected over a $24 \mathrm{~h}$ period, the volume was measured, and the urines were examined for clinical proteinuria, glycosuria and haematuria using Labstix ${ }^{\circledR}$ (Ames). Microscopic examination of the urine sediment was carried out after centrifugation at $800 \mathrm{rev} . / \mathrm{min}$ for $10 \mathrm{~min} .20 \mathrm{ml}$ portions of the urine samples were dialyzed against running tap water for $24 \mathrm{~h}$, using dialysis tubing No. 15109-400 (Kalle AG, Wiesbaden). The dialysed non-concentrated urine samples were examined for protein content by the method of Kjeldahl [19]. The activity of U-LDH was determined by the method mentioned above. As previously described [13], the fractionation of the proteins was carried out by means of disc electrophoresis. The proteins were stained with Amido Schwartz, and the LDH isoenzymes were developed with the nitrobluetrazolium method of Goldberg [10]. The protein fractions and the LDH isoenzymes were scanned on a Vitatron Universal Densitometer. After disc electrophoresis, the protein fractions were identified by their relative mobilities $\left(R_{M}\right)$, using transferrin as reference $\left(R_{M}=1.00\right)$. We decided to describe five specific fraction areas, although it is possible, inconstantly, to detect several others.

The selected areas are: Prealbumin $\left(R_{M}>1.85\right)$, albumin $\left(R_{M}=1.85\right)$, postalbumin $\left(R_{M}<1.85 \& R_{M}>\right.$ $1.00)$, transferrin $\left(R_{M}=1.00\right)$ and gammaglobulin $\left(R_{M}<1.00\right.$ and $\left.R_{M}>0.00\right)$.

The LDH isoenzymes were also identified by their relative mobilities. The five $\mathrm{LDH}$ isoenzymes we describe are: LDH-I $\left(R_{M}=1.30\right)$, LDH-II $\left(R_{M}=1.00\right)$, LDH-III $\left(R_{M}=0.75\right), \quad$ LDH-IV $\quad\left(R_{M}=0.30\right)$ and LDH.V $\left(R_{M}=0.00\right)$.

$24 \mathrm{~h}$ urine samples from 80 patients with DM have been examined.

The following criteria for the diagnosis and investigation have been used:

1. Fasting blood sugar $>140 \mathrm{mg} / 100 \mathrm{ml}$, measured on capillary blood (potassium ferricyanide reduction method, normal range: $<120 \mathrm{mg} / 100 \mathrm{ml}$ ).

2. If the fasting blood sugar is $\geq 120 \mathrm{mg} / 100 \mathrm{ml}$ and $\leq 140 \mathrm{mg} / 100 \mathrm{ml}$, a $21 / 2 \mathrm{~h}$ glucose tolerance test is performed. The blood sugar of the patients in this investigation exceeded $120 \mathrm{mg} / 100 \mathrm{ml}$ after $2^{1 /} / 2 \mathrm{~h}$.

3 . At the time of the investigation none of the patients displayed ketonuria.

We have excluded 7 diabetics in whom other diseases were a possible cause of proteinuria. The final material therefore consists of $\mathbf{7 3}$ patients, classified according to the WHO Expert Committee on Diabetes Mellitus 1966 [24]. This classification is based on age of recognized onset of the diabetes. We have combined Infantile and Young Diabetes into one group: Juvenile Diabetes (JDM), age $0-24$ years, acceptable in a non-tropical clinical material. Adult Diabetes (ADM) includes the age group 25-64 years. Elderly Diabetes (EDM) includes patients older than 64 years.

Some subgroups are also considered:

1. Recent Juvenile Diabetes Mellitus (Recent JDM) has a duration of less than one year. Recent Adult and especially Recent Elderly Diabetes Mellitus (Recent ADM and Recent EDM) are not well defined as clinical entities because recognition of the diabetes is often preceded by a long subclinical course. At the time of diagnosis, such patients not infrequently present long-term diabetic complications. Thus the Recent ADM and the Recent EDM in this material have not been differentiated from the other patients in $\mathrm{ADM}$ and EDM.

2. Diabetic nephropathy is, in this investigation, defined as a daily protein excretion $\geq 500 \mathrm{mg} / 24 \mathrm{~h}$. This limit has been chosen because it invariably corresponds to a positive Labstix ${ }^{\circledR}$, and because there is a division in the material at this level.

3. Diabetics with obesity are defined as weighing $10 \mathrm{~kg}$ or more than the calculated normal weight $(\mathrm{kg}=$ height in $\mathrm{cm}-100)$.

4. Insulin-dependent diabetics.

Analysis by sex is not displayed in this paper because statistical calculations demonstrated no difference between the two sexes.

\section{Results}

The normal material is made up of 47 healthy persons, 24 females and 23 males, between 19 and 56 years of age, (average 33 years for both sexes).

The normal subjects showed no clinical proteinuria, glycosuria or haematuria, and microscopy of the urine was normal. The average $24 \mathrm{~h}$ diuresis is $1300 \mathrm{ml}$. The average protein excretion was $121 \mathrm{mg} / 24 \mathrm{~h}$ with a 0.95-Range of $33-209 \mathrm{mg} / 24 \mathrm{~h}$, identical for the two sexes. The average excretion of U.LDH was 6000 i.u./24 h with a 0.95 -Range of $0-14000$ i.u. $/ 24 \mathrm{~h}$. The percentage distribution and the excretion of the protein fractions is given in Table 3 . The percentage distribution of the LDH isoenzymes is given in Table 4.

Table 2 presents the average $24 \mathrm{~h}$ protein excretion. On average, JDM excrete more than ADM, and EDM excrete the least of the three groups. Excluding patients with nephropathy, the same three groups show no significant differences in protein-excretion, and do not differ significantly from recent JDM. However, the average urinary protein excretion for all diabetics without nephropathy $(227 \mathrm{mg} / 24 \mathrm{~h})$ is significantly higher than the protein-excretion in the normals $(p<0.001)$. The Recent. JDM also have a significantly higher protein excretion (214 $\mathrm{mg} / 24 \mathrm{~h}$ ) than the normal $(p<0.05)$. The chosen diagnostic limit for nephropathy $(500 \mathrm{mg} / 24 \mathrm{~h})$ is higher than the upper limit of all diabetics without nephropathy $(0.95-$ Range: $0-447 \mathrm{mg}$ ). The average protein excretion from all diabeties with nephropathy is also listed in Table 2 .

Table 2 also shows the average daily excretion of U-LDH. The Recent JDM and JDM without nephropathy, ADM without nephropathy and EDM without nephropathy do not differ significantly from 
Table 1. 73 Patients with diabetes mellitus classified according to the criteria recommended by WHO

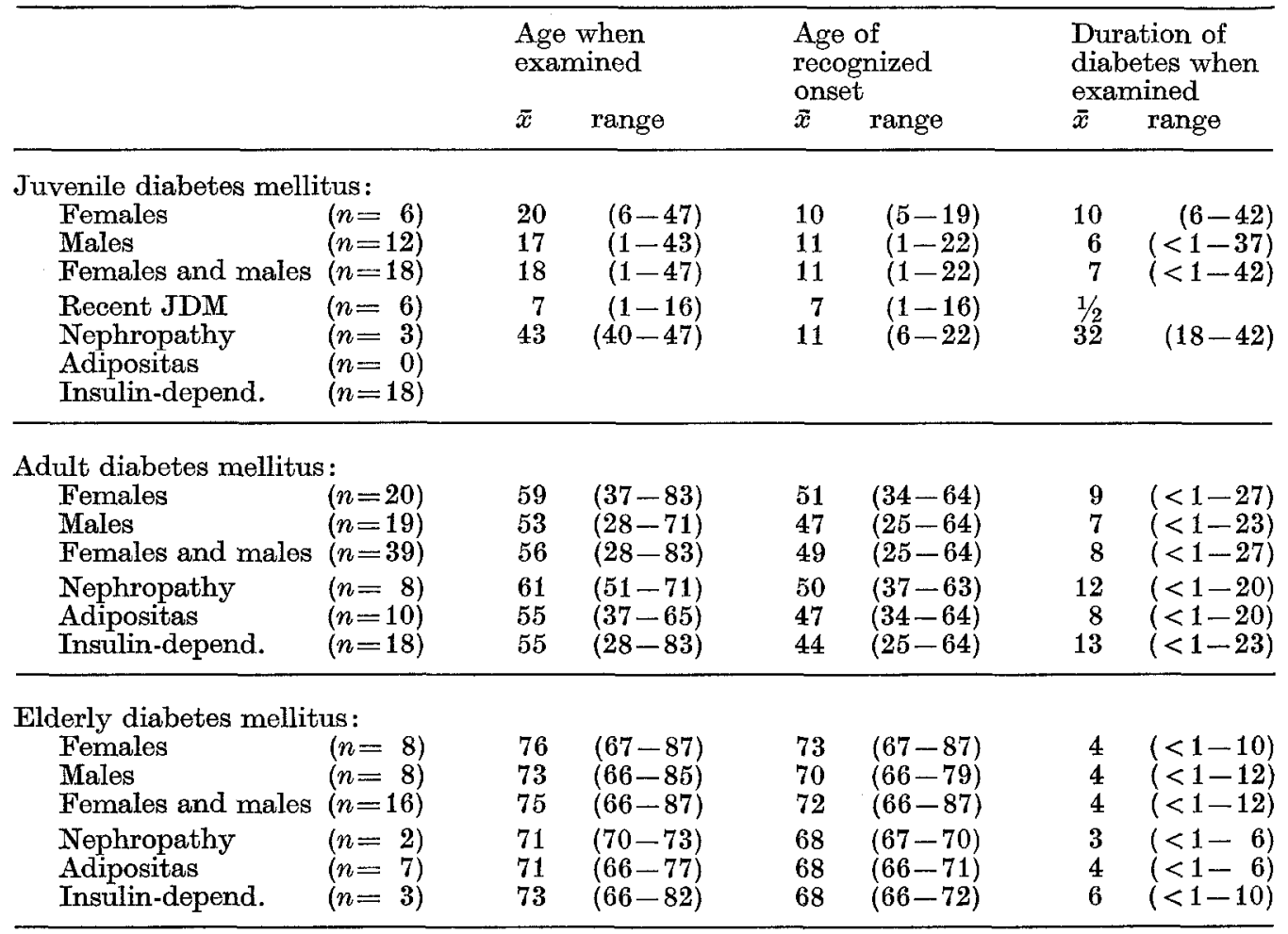

$n=$ number of patients; age and duration in years

Table 2. The daily excretion of urinary protein and lactic acid dehydrogenase in the normal and in patients with diabetes mellitus

\begin{tabular}{lccc}
\hline & & $\begin{array}{c}\text { Protein } \\
\text { excretion } \\
\text { mg/24-h }\end{array}$ & $\begin{array}{r}\text { U-LDH } \\
\text { excretion } \\
\text { i.u. } / 24 \mathrm{~h}\end{array}$ \\
\hline Normal material & $(n=47)$ & $\mathbf{1 2 1}$ & 6000 \\
Standard DV. & $(n=6)$ & 214 & 4000 \\
Recent JDM & & 68 & 7000 \\
Standard DV. & $(n=60)$ & 227 & $\mathbf{7 0 0 0}$ \\
Diabetics, without nephropathy & & 100 & 10000 \\
Standard DV. & $(n=13)$ & 1951 & 15000 \\
Diabetics, with nephropathy & & 1633 & 14000 \\
Standard DV. & $(n=18)$ & 597 & 11000 \\
Juvenile diabetes mellitus & $(n=15)$ & 222 & 9000 \\
Juvenile, without nephropathy & $(n=3)$ & $\mathbf{2 4 6 9}$ & $\mathbf{2 2 0 0 0}$ \\
Juvenile, with nephropathy & $(n=39)$ & 589 & 12000 \\
\hline Adult diabetes mellitus & $(n=31)$ & 221 & 11000 \\
Adult, without nephropathy & $(n=8)$ & 2017 & 15000 \\
Adult, with nephropathy & $(n=16)$ & $\mathbf{3 3 0}$ & $\mathbf{1 1 0 0 0}$ \\
\hline Elderly diabetes mellitus & $(n=14)$ & $\mathbf{2 4 7}$ & $\mathbf{1 1 0 0 0}$ \\
Elderly, without nephropathy & $(n=\mathbf{2})$ & 912 & $\mathbf{5 0 0 0}$ \\
\hline Elderly, with nephropathy & & & \\
\hline
\end{tabular}

$n=$ number of patients 
each other. As with protein excretion, the excretion of U-LDH in all diabetics without nephropathy is significantly higher than the excretion in the normal $(p<0.01)$. The U-LDH excretion of Recent JDM does not differ significantly from the normals, and all diabetics with nephropathy demonstrate elevation of low significance compared with the normals $(p<0.1)$. The excretion of U-LDH in the diabetics with nephropathy demonstrates a fall from the juvenile through the adult to the elderly, similar to the protein excretion.

Table 3 gives the average percentage distribution of the proteins in the five fraction areas. The protein pattern differs characteristically in the groups without nephropathy from the groups with nephropathy. Recent JDM demonstrates a characteristic protein pattern with a significantly lower proportion of albumin $(p<0.02)$ than the normal. The protein pattern of albumin is higher $(73 \%, p<0.001)$, of postalbumin is lower $(10 \%, p<0.001)$, and of transferrin is higher $(8 \%, p<0.02)$ than in the normals.

We have tried to describe the most characteristic changes in the protein pattern by means of the selectivity of the proteinuria. The selectivity in our material is calculated by means of a factor. This factor is defined as the proportion between the average protein excretion in the patient group and the average protein excretion in the normal material within the fraction area concerned. The percentage distribution of the factors, calculated for the fraction areas, gives us the selectivity of the proteinuria (Fig. 1). A high percentage value within a specific fraction means a high selectivity. All diabetics with nephropathy demonstrate selectivity for albumin (31\%) and transferrin $(35 \%)$. All diabetios without nephropathy demonstrate a low selectivity for transferrin $(25 \%)$ and gammaglobulin

Table 3. The protein-pattern in urine from the normal and from patients with diabetes mellitus

\begin{tabular}{|c|c|c|c|c|c|c|}
\hline & & $\begin{array}{l}\text { Pre- } \\
\text { alb. } \\
\%\end{array}$ & $\underset{\%}{\text { Albu- }}$ & $\begin{array}{l}\text { Post- } \\
\text { alb. } \\
\%\end{array}$ & $\begin{array}{l}\text { Trans- } \\
\text { ferrin } \\
\%\end{array}$ & $\begin{array}{l}\text { Gamma- } \\
\text { glob. } \\
\%\end{array}$ \\
\hline $\begin{array}{l}\text { Normal material } \\
\text { Standard DV. }\end{array}$ & $(n=47)$ & $\begin{array}{r}11 \\
7\end{array}$ & $\begin{array}{l}51 \\
14\end{array}$ & $\begin{array}{l}25 \\
10\end{array}$ & $\begin{array}{l}\mathbf{5} \\
\mathbf{3}\end{array}$ & $\begin{array}{l}7 \\
5\end{array}$ \\
\hline $\begin{array}{l}\text { Recent JDM } \\
\text { Standard DV. }\end{array}$ & $(n=6)$ & $\begin{array}{l}18 \\
10\end{array}$ & $\begin{array}{r}39 \\
6\end{array}$ & $\begin{array}{l}21 \\
12\end{array}$ & $\begin{array}{l}8 \\
4\end{array}$ & $\begin{array}{r}14 \\
8\end{array}$ \\
\hline $\begin{array}{l}\text { Diabetics, without nephropathy } \\
\text { Standard DV. }\end{array}$ & $(n=60)$ & $\begin{array}{r}10 \\
7\end{array}$ & $\begin{array}{l}51 \\
14\end{array}$ & $\begin{array}{l}22 \\
12\end{array}$ & $\begin{array}{l}7 \\
4\end{array}$ & $\begin{array}{l}9 \\
7\end{array}$ \\
\hline $\begin{array}{l}\text { Diabetics, with nephropathy } \\
\text { Standard DV. }\end{array}$ & $(n=13)$ & $\begin{array}{l}3 \\
2\end{array}$ & $\begin{array}{l}73 \\
14\end{array}$ & $\begin{array}{r}10 \\
9\end{array}$ & $\begin{array}{l}8 \\
3\end{array}$ & $\begin{array}{l}6 \\
4\end{array}$ \\
\hline $\begin{array}{l}\text { Juvenile diabetes mellitus } \\
\text { Juvenile, without nephropathy } \\
\text { Juvenile, with nephropathy }\end{array}$ & $\begin{array}{l}(n=18) \\
(n=15) \\
(n=3)\end{array}$ & $\begin{array}{r}12 \\
15 \\
3\end{array}$ & $\begin{array}{l}51 \\
46 \\
72\end{array}$ & $\begin{array}{l}19 \\
21 \\
10\end{array}$ & $\begin{array}{l}7 \\
7 \\
8\end{array}$ & $\begin{array}{r}10 \\
11 \\
6\end{array}$ \\
\hline $\begin{array}{l}\text { Adult diabetes mellitus } \\
\text { Adult, without nephropathy } \\
\text { Adult, with nephropathy }\end{array}$ & $\begin{array}{l}(n=39) \\
(n=31) \\
(n=8)\end{array}$ & $\begin{array}{l}8 \\
9 \\
3\end{array}$ & $\begin{array}{l}55 \\
50 \\
72\end{array}$ & $\begin{array}{l}20 \\
23 \\
10\end{array}$ & $\begin{array}{l}8 \\
8 \\
8\end{array}$ & $\begin{array}{l}9 \\
9 \\
7\end{array}$ \\
\hline $\begin{array}{l}\text { Elderly diabetes mellitus } \\
\text { Elderly, without nephropathy } \\
\text { Elderly, with nephropathy }\end{array}$ & $\begin{array}{l}(n=16) \\
(n=14) \\
(n=2)\end{array}$ & $\begin{array}{l}6 \\
7 \\
3\end{array}$ & $\begin{array}{l}61 \\
58 \\
79\end{array}$ & $\begin{array}{l}18 \\
19 \\
11\end{array}$ & $\begin{array}{l}7 \\
7 \\
5\end{array}$ & $\begin{array}{l}7 \\
8 \\
2\end{array}$ \\
\hline
\end{tabular}

$n=$ number of patients

in the groups without nephropathy is very similar to the protein pattern of the normal. A small difference between the jurenile group and the elderly group can be seen. The most characteristic difference when the groups without nephropathy are compared with the normals is the higher transferrin percentage $(p<0.01)$ and gammaglobulin percentage $(p<0.1)$ in the former. There are only small differences between JDM with nephopathy, ADM with nephropathy and EDM with nephropathy. Taken together, all diabetics with nephropathy demonstrate a characteristic protein pattern which differs significantly from the normal within all the fraction areas except gammaglobulin. The proportion of prealbumin is lower $(3 \%, p<0.001)$,
(24\%). Recent JDM demonstrates selectivity for prealbumin $(24 \%)$ and gammaglobulin $(30 \%)$. In Fig. 1 the evolution of the selectivity from Recent JDM to all diabetics without nephropathy and all diabetics with nephropathy is clearly illustrated within each protein fraction.

Table 4 gives the average percentage distribution of the five LDH-isoenzymes. LDH.I is lower than in the normal within all the diabetic groups. The difference is significant except in Recent JDM. An increase in LDH-III is also demonstrated in Recent JDM $(8 \%)$ through JDM without nephropathy $(13 \%)$, ADM without nephropathy $(15 \%)$ to EDM without nephropathy $(23 \%)$. The same change in LDH-III is 
demonstrated within JDM with nephropathy $(8 \%)$, ADM with nephropathy $(21 \%)$ and EDM with nephropathy $(34 \%)$.

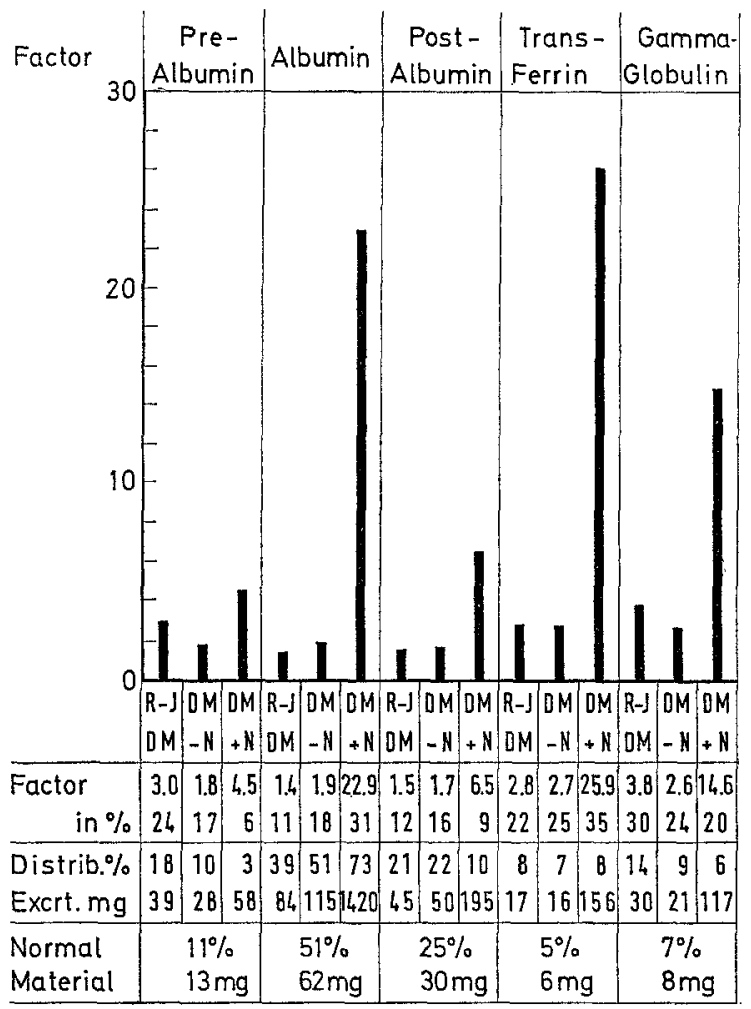

Fig. 1. By means of factor calculation the selectivity of the proteinuria is demonstrated in recent JDM (R-JDM), diabetics without nephropathy (DM-N) and diabetics with nephropathy $(\mathrm{DM}+\mathrm{N})$. The percentage distribution of the proteins and the excretion of the protein fractions within the same groups and the Normals is also shown
All diabetics, with nephropathy and without nephropathy, differ significantly from the normals. Both groups demonstrate a significantly lower LDH-I and a significantly higher LDH-III compared with the normals. Moreover, all diabetics without nephropathy demonstrate elevated LDH-IV and LDH-V $(p<0.05$ in all fractions). We have calculated the correlation between the duration of the disease in JDM and the other measured parameters. We have found positive correlation with the protein excretion $(r=0.76)$, albumin concentration $(r=0.56)$ and the U-LDH-excretion $(r=0.62)$. We have found negative correlation with concentrations of prealbumin $(r=-0.51)$, postalbumin $(r=-0.52)$ and gammaglobulin $(r=-0.79)$. Further, we have found that there is no large increase in protein excretion in JDM until more than 10 years of the disease have passed. Similar calculations have been made on ADM and EDM, but it is not possible to draw any conclusions in these two groups, possibly because of a long subclinical course, which makes the determination of the true duration of the disease uncertain.

We have calculated the correlation between the protein excretion and the other measured parameters, and have found it positively correlated with the U. LDH-excretion in JDM $(r=0.70)$ and with serum creatinine in all diabetics: $(r=0.66)$.

Finally, we have compared all diabetics with nephropathy with all diabetics without nephropathy. The difference in protein excretion between the two groups is obvious by definition. The protein pattern is also differs significantly. Diabetics with nephropathy demonstrate a lower prealbumin $(p<0.001)$, postalbu$\min (p<0.01)$ and gammaglobulin $(p<0.05)$. At the same time albumin is significantly higher $(p<0.001)$.

Table 4. $L D H$-isoenzyme-pattern in urine from the normal and from patients with diabetes mellitus

\begin{tabular}{|c|c|c|c|c|c|c|}
\hline & & $\underset{\%}{\operatorname{LDH}}-\mathrm{I}$ & $\underset{\%}{\text { LDH-II }}$ & $\underset{\%}{\mathrm{LDH}-\mathrm{III}}$ & $\begin{array}{l}\text { LDH-IV } \\
\%\end{array}$ & $\underset{\%}{\mathrm{LDH}}$ \\
\hline $\begin{array}{l}\text { Normal material } \\
\text { Standard DV. } \\
\text { Recent JDM } \\
\text { Standard DV. } \\
\text { Diabetics, without nephropathy } \\
\text { Standard DV. } \\
\text { Diabetics, with nephropathy } \\
\text { Standard DV. }\end{array}$ & $\begin{array}{l}(n=47) \\
(n=6) \\
(n=60) \\
(n=13)\end{array}$ & $\begin{array}{l}58 \\
11 \\
46 \\
14 \\
44 \\
15 \\
32 \\
12\end{array}$ & $\begin{array}{r}29 \\
8 \\
32 \\
6 \\
27 \\
9 \\
33 \\
13\end{array}$ & $\begin{array}{r}7 \\
6 \\
8 \\
6 \\
16 \\
13 \\
17 \\
11\end{array}$ & $\begin{array}{r}4 \\
6 \\
10 \\
5 \\
9 \\
8 \\
8 \\
7\end{array}$ & $\begin{array}{l}\mathbf{2} \\
\mathbf{3} \\
\mathbf{4} \\
\mathbf{3} \\
\mathbf{3} \\
\mathbf{5} \\
\mathbf{2} \\
\mathbf{2}\end{array}$ \\
\hline $\begin{array}{l}\text { Juvenile diabetes mellitus } \\
\text { Juvenile, without nephropathy } \\
\text { Juvenile, with nephropathy }\end{array}$ & $\begin{array}{l}(n=18) \\
(n=15) \\
(n=3)\end{array}$ & $\begin{array}{l}42 \\
44 \\
35\end{array}$ & $\begin{array}{l}31 \\
30 \\
36\end{array}$ & $\begin{array}{r}12 \\
13 \\
8\end{array}$ & $\begin{array}{r}10 \\
8 \\
16\end{array}$ & $\begin{array}{l}5 \\
5 \\
4\end{array}$ \\
\hline $\begin{array}{l}\text { Adult diabetes mellitus } \\
\text { Adult, without nephropathy } \\
\text { Adult, with nephropathy }\end{array}$ & $\begin{array}{l}(n=39) \\
(n=31) \\
(n=8)\end{array}$ & $\begin{array}{l}43 \\
45 \\
36\end{array}$ & $\begin{array}{l}30 \\
29 \\
37\end{array}$ & $\begin{array}{l}16 \\
15 \\
21\end{array}$ & $\begin{array}{l}9 \\
9 \\
6\end{array}$ & $\begin{array}{l}\mathbf{3} \\
\mathbf{3} \\
\mathbf{1}\end{array}$ \\
\hline $\begin{array}{l}\text { Elderly diabetes mellitus } \\
\text { EIderly, without nephropathy } \\
\text { Elderly, with nephropathy }\end{array}$ & $\begin{array}{l}(n=16) \\
(n=14) \\
(n=2)\end{array}$ & $\begin{array}{l}41 \\
45 \\
20\end{array}$ & $\begin{array}{l}22 \\
22 \\
34\end{array}$ & $\begin{array}{l}23 \\
23 \\
34\end{array}$ & $\begin{array}{r}7 \\
8 \\
12\end{array}$ & $\begin{array}{l}1 \\
1 \\
1\end{array}$ \\
\hline
\end{tabular}

$n=$ number of patients 
The only significant differences between all diabetics with nephropathy and all diabetics without nephropathy in relation to the U.LDH-excretion and the $\mathrm{LDH}$ isoenzyme pattern are, a lower LDH-I $(p<0.1)$ and a lower LDH-V $(p<0.05)$ in the nephropathy group.

\section{Discussion and Conclusions}

Of the clinical features which characterize diabetic nephropathy, increased excretion of protein in the urine ("proteinuria") has been recognized as the initial clinical sign.

In the present study we have shown that diabeties demonstrate increased excretion of protein in $24 \mathrm{~h}$-urine from the recognized onset of the disease. This can be compared with the investigations of Keen and Chlouverakis [17], which demonstrated increased excretion of albumin in $2 \mathrm{~h}$-urine collections from recently discovered diabetics. The patients investigated in that study constituted diabetics of all ages, most of them old people. The group of patients is thus less welldefined than ours and cannot be compared with the Recent JDM in our material.

We found, like Keen and Chlouverakis, that testing the urine with Labstix ${ }^{\circledR}$ may fail to show the presence of increased excretion of protein until it exceeds $500 \mathrm{mg} / 24 \mathrm{~h}$. The explanation is, among other reasons, the large $24 \mathrm{~h}$-urine volume of many diabetics. We therefore recommend the use of more sensitive methods, such as the method of Kjeldahl, in order to detect the increased excretion of protein in urine from diabetics, especially in Recent diabetics and in diabetics without nephropathy.

It is interesting that this investigation has shown that, compared with the normal, recent JDM demonstrated a statistically significant reduction in the proportion of urinary albumin. The absolute excretion of albumin was however slightly increased. These alterations in the excretion of protein and the protein pattern in urine from Recent JDM, can possibly be related to the electron microscopic changes demonstrable in JDM soon after the onset of the disease $[12,27,5,26]$. It may also be connected with the increased glomerular filtration rate in the same group of patients, demonstrated by Ditzel et al. [6].

Disc electrophoresis has not previously been used to characterize the selectivity of the proteinuria in diabetics. Its use in the present study, together with the factor calculation introduced in this paper, has demonstrated characteristic patterns and changes in the selectivity of the proteinuria in diabetics. In Recent JDM, the selectivity was found in the fractions of prealbumin and especially gammaglobulin. In diabetics without nephropathy, low selectivity was found in the fractions of transferrin and gammaglobulin. In diabetics with nephropathy, high selectivity was found in the fractions of albumin and transferrin.

Our modification of disc electrophoresis, together with factor calculations, has been valuable in defining the selectivity of proteinuria. It may also have therapeutic implications, as in the treatment of proteinuria in diseases other than DM $[3,15,8,16]$.

In accordance with other authors $[28,20,21,4]$, this investigation has shown that in JDM a large rise in excretion of protein is found after a diabetes duration of more than 10 years. Moreover in JDM we have demonstrated a quantitative relationship between duration of the diabetes and the excretion of protein, the protein pattern and the excretion of U-LDH. Like other workers, we have been unable to demonstrate a relationship between obesity or insulin treatment and the course of the proteinuria. As a matter of fact, we have found that patients treated with insulin and obese patients do not differ from the other patients in this study. We have therefore only used those two subgroups in the description of the patients in this paper (Table 1, see page 514).

In Table 1 one will find that in accordance with other authors [22] there is a substantial number of normal-weight or under-weight, insulin-treated patients especially in the ADM-group but also in the EDMgroup. This confirms the fact that in these two groups $(\mathrm{ADM}+\mathrm{EDM})$, a considerable number of diabetics present with features in common with the juvenile type of diabetes. JDM in contrast is a uniform group, all patients being treated with insulin and none overweight.

In JDM the U-LDH-excretion was a fairly reliable method for assessing the severity of the nephropathy as judged by the correlation between protein excretion and U-LDH-excretion in JDM. The U-LDH excretion was not significantly increased in Recent JDM, and therefore is not as sensitive as the protein-excretion in detecting the onset of the change in kidney function in diabetics. In the other groups of diabetics, the correlation between protein excretion and U-LDH excretion was also less good. This apparent difference in reliability is in accord with similar disagreements, reported by different authors, on the diagnostic reliability of the U-LDH excretion in a variety of diseases of the kidney $[9,18,25,1]$. The LDH isoenzyme pattern showed distinct changes compared with normal in all the diabetic groups. The most characteristic feature was a low LDH-I. Theories of the influence of oxygen tension on the LDH isoenzyme pattern [2, 23, $7,11]$, would explain this pattern as evidence of alteration of the metabolism of the kidney towards anaerobic conditions.

The LDH isoenzyme pattern is just as sensitive as the protein excretion in detecting the onset of the change in the kidney function in diabetics. It is not so useful for measuring the severity and evolution of the nephropathy.

From the above, the following conclusions can be drawn:

1. Urinary protein excretion is increased right from the onset of DM. 
2. Major rises in protein excretion are seen after more than 10 years duration of the diabetes in JDM. In this group, there is a good correlation between the duration of the disease and the protein excretion, protein pattern and U-LDH excretion.

3. Although the U-LDH excretion in JDM is correlated with the protein excretion, the U-LDH excretion is not as sensitive a method as the protein excretion, and it is less reliable in other groups of diabetics.

4. All groups of diabetics demonstrate low LDH-I and different degrees of elevation of the other LDH fractions. The LDH isoenzymes are reliable in detecting the early stages of altered function of the diabetic kidney. They are less useful for judging the severity of the nephropathy.

The most interesting two groups of diabetics can be described as follows:

5. Recent JDM are different from the normal in the following points: increased protein excretion, and a characteristic protein pattern presenting low albumin percentage and, by means of factor calculations selective proteinuria in the fractions of gammaglobulin and to a less degree prealbumin. LDH-I is low.

6. The features of diabetics with nephropathy are not only the expected increased protein excretion, but also a characteristic protein pattern presenting a high proportion of albumin. Factor calculations show highly selective proteinuria in the fractions of albumin and transferrin. The U-LDH excretion is increased and LDH-I is low.

7. Although diabetics with nephropathy differ from diabetics without nephropathy in their protein excretion and protein pattern, they differ only slightly in LDH-isoenzyme pattern and not at all in the U.LDH excretion.

\section{References}

1. Amador, E., Dorfman, L. E., Wacker, Warren, E.C.: Urinary alkaline phosphatase and LDH activities in the differential diagnosis of renal disease. Ann. intern. Med. 62, 30-40 (1965).

2. Cahn, R.D., Kaplau, N.O., Levine, L., Zwilling, E.: Nature and development of lactic dehydrogenases. Science 136, 962-969 (1962).

3. Cameron, J.S., White, R.H.R. : Selectivity of proteinuria in children with the nephrotic syndrome. Lancet 1965 I, $463-465$.

4. Dachs, S., Churg, J., Mautner, W., Grishman, E.: Diabetic nephropathy. Amer. J. Path. 44, 155-168(1964)

5. Daysog, A., Jr., Dobson, H.L., Brennan, J.C.: Renal glomerular and vascular lesions in prediabetes and in diabetes mellitus: A study based on renal biopsies. Ann. intern. Med. 54, 672-684 (1961).

6. Ditzel, J.: Glomerular filtration rates in relation to abnormal vascular patterns in early diabetes mellitus, p. 509-515. 4.th. European Conference on Microcirculation, Cambridge. Basel: S. Karger 1966.
7. Farriaux, J.-P., Han, K., Fontaine, G., Havez, R.: La lactico-déshydrogénase revue critique. Path. Biol. 15, 299-312 (1967).

8. Flynn, F.V., Platt, H.S.: The origin of the proteins excreted in tubular proteinuria. Clin. chim. Acta 21, $377-399$ (1968).

9. Glenert, J., Femmingsen, L., Juul, P., Søgaard-Andersen, I: Mælkesyredehydrogenaseaktiviteten i urinen hos patienter med nyre- og urinvejssygdomme. Nord. Med. 76, 1274-1276 (1966).

10. Goldberg, E.C.: Lactic and malic dehydrogenases in human spermatozoa. Science 139, 602-603 (1963).

11. Güttler, F., Clausen, I., Pedersen, A., Schiøler, M.: Mælkesyredehydrogenase-isoenzymmønstret i nyre. bækkenurin fra patienter med hypertension. Ugeskr. f. Læger. 125, $1551-1556$ (1963).

12. Hansen, R., Østerby: A quantitative estimate of the peripheral glomerular basement membrane in recent juvenile diabetes. Diabetologia 1, 97-100 (1965).

13. Hemmingsen, L., Øther, A.: Dise electrophoresis of aqueous humour. Acta ophthal. 45, 359-369 (1967).

14. - Skov, F.: The protein and LDH isoenzyme pattern of normal human urine determined by polyacrylamide gel disc electrophoresis. Clin. chim. Acta 19, $81-87$ (1968).

15. Jensen, H.: Plasma protein metabolism in the nephrotic syndrome. Copenhagen: Munksgaard 1969.

16. Joachim, G.R., Cameron, J.S., Schwartz, M., Becker, E.L.: Selectivity of protein exeretion in patients with the nephrotic syndrome. J. clin. Invest. 43, 23322346 (1964).

17. Keen, H., Chlouverakis, C.: Urinary albumin exeretion and diabetes mellitus. Lancet 1964 II, 11551156.

18. Kemp, E., Laursen, T.: Investigations of the excretion of enzymes in urine. Scand. J. clin. Lab. Invest. 12, $463-471(1960)$.

19. Kjeldahl, J.: En ny metode til kvælstofbestemmelse i organiske stoffer. Medd. fra Carlsberglaboratoriet, II. bind, I. hæfte 1-27, 1883.

20. Lundbæk, K.: Long-term diabetes, p. 40-78. Copenhagen: Munksgaard 1965.

21. - Nephropathy in diabetic subjects. Excerpta med. Int. Congr. Ser. 84, 436-446 (1965).

22. Nielsen, Sv. E., Lund Andresen, J., Rafaelsen, I.O.: Diabetes mellitus debuterende efter 40 års alderen. Ugeskr. Læg. 131, $227-234$ (1969).

23. Pfleiderer, Wachsmuth, E. D.: Alters- und funktionsabhängige Differenzierung der Lactatdehydrogenase menschlicher Organe. Biochem. Z. 334, 185198 (1961).

24. Poulsen, J.E.: Diabetes mellitus. Acta endocr. Suppl. 118, $16-18$ (1967)

25. Riggins, R.S., Kiser, W.S.: A study of lactic dehydrogenase in urine and serum of patients with urinary tract disease. J. Urol. 90, 594-601 (1963).

26. Rosenbaum, P., Kattine, A. A., Gottsegen, W.L.: Diabetic and prediabetic nephropathy in childhood. Amer. J. Dis. Child. 106, 83-95 (1963).

27. Sabour, M.S., MacDonald, Mary, K., Robson, J.S.: An electron microscopic study of the human kidney in young diabetic patients with normal renal function. Diabetes 2, $291-295$ (1962).

28. Thomsen, Aa., Chr.: The kidney in diabetes mellitus, Kap. 11, p. 131 - 152. Copenhagen: Munksgaard 1965.

\author{
Dr. L. Hemmingsen \\ Central Hospital \\ DK-4800 Nykøbing Falster
}

